This article was downloaded by: [Monash University Library]

On: 06 J anuary 2015, At: 12:19

Publisher: Routledge

Informa Ltd Registered in England and Wales Registered Number: 1072954

Registered office: Mortimer House, 37-41 Mortimer Street, London W1T

3J H, UK

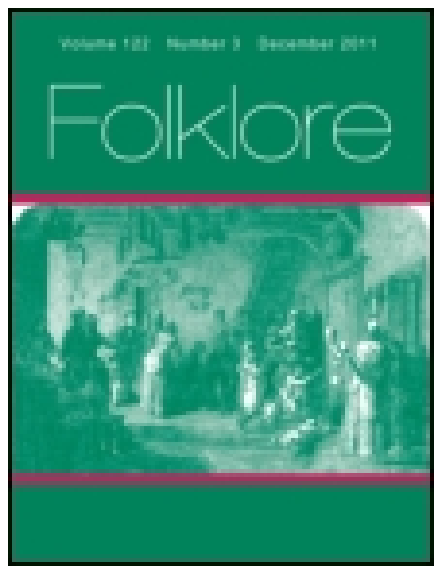

\title{
Folklore
}

Publication details, including instructions for authors and subscription information:

http:// www. tandfonline.com/loi/ rfol20

\section{Report upon the Progress of Study During the Past Eighteen Months}

Alfred Nutt

Published online: 14 Feb 2012.

To cite this article: Alfred Nutt (1890) Report upon the Progress of Study During the Past Eighteen Months, Folklore, 1:2, 236-260, DOI: 10.1080/ 0015587X.1890.9720009

To link to this article: http:// dx. doi.org/ 10.1080/0015587X.1890.9720009

\section{PLEASE SCROLL DOWN FOR ARTICLE}

Taylor \& Francis makes every effort to ensure the accuracy of all the information (the "Content") contained in the publications on our platform. However, Taylor \& Francis, our agents, and our licensors make no representations or warranties whatsoever as to the accuracy, completeness, or suitability for any purpose of the Content. Any opinions and views expressed in this publication are the opinions and views of the authors, and are not the views of or endorsed by Taylor \& Francis. The accuracy of the Content should not be relied upon and should be independently verified with primary sources of information. Taylor and Francis shall not be liable for any losses, actions, claims, proceedings, demands, costs, expenses, damages, and other liabilities whatsoever or howsoever caused arising directly or indirectly in connection with, in relation to or arising out of the use of the Content.

This article may be used for research, teaching, and private study purposes. Any substantial or systematic reproduction, redistribution, reselling, loan, sub-licensing, systematic supply, or distribution in any form to anyone is 
expressly forbidden. Terms $\&$ Conditions of access and use can be found at http://www.tandfonline.com/page/terms-and-conditions 


\section{CELTIC MYTH AND SAGA.}

Report UPON THE PROgRess OF STUdy DORING THE

PAST Eighteen MONTHS.

H. Zrarrer Keltische Beitrodge, ii : Brendan's Meerfahrt. (Zeitsckrift für deutschesAlterthum, vol, xxoiii, Nos. 2-4.) Berlin, 1889.

G. Schirmer. Zur Brendenus Legende. Leipzig, 1888.

Anecdota Oxoniensian. Mediaval and Modern Series, part v. Lives of Saints from the Book of Lismore, edited by Whitley Stokes, D.C.L. Oxford, 1890 .

ARChDRACON T. O'RORKR. The History of Sligo, 2 vols. Dublin, 1889.

Sophix Bryant. Celtic Ireland. London, 1889.

LADY FERGUSON. The Story of Ireland before the Conguest. 2nd ed. Dublin, 1890.

Histoire Litteraire dé La France, tome $20 x$. Paris, 1888.

W. GolTHER, Die Frage nach der Entstehung der bretonischen und Arthur Epen. (Zeitschrift für Literaturgesel., vol, iii)

K. OTHMER. Das Verhältniss von Christian von Troyes "Erec of Enide" su dem Mabinogion. Cologne, r88g.

, LADY WILDE. Ancient Curres, Charms, and Usages of Ireland. London, 1889.

Folk and Horo Tales from Argyllshire, edited by the Rev. D. MacInnes, with notes by Alfred Nutt (quoted in this article as Tales).

J. CuRTIN. Myths and Folk-Lore of Ireland London, 1890 .

D. MACRITCHIE. "The Finn-Men of Britain", "British Dwarfs", "Earth-houses and their Inhabitants" (Arch. Rev, vol. iv). London, 1889.

$\mathrm{N}$ an article which appeared in these pages (Arch. Review, Oct. 1888), and which this present one supplements and continues, I expressed the opinion that, "except the Hellenic, the Irish sagas are the only considerable mass of Aryan epic tradition almost entirely uninfluenced by Christianity. As evidence of the most 
archaic side of Aryan civilisation, the Tain bó Cuailgne is "only inferior to the Iliad or the Odyssey."

This is one way of looking at the remains of early Irish mythic and saga literature, and, if it be the correct one, it is not easy to over-estimate the importance of this literature to the folk-lorist in general, and in especial to students of British folk-lore. For if we hold that the beliefs and customs of archaic Ireland are to a large extent preserved in the early literature, it is natural to assume that these beliefs and customs were also shared by the inhabitants of archaic Britain, and it is an equally natural assumption that some of these beliefs and customs are still enshrined in the folklore current in the islands. This series of assumptions underlies a number of works which have been written of late years, notably Professor Rhys's Hibbert Lectures, of which I gave a full account in the above-cited article, and the papers by Mr. G. I. Gomme, which have appeared in these pages. ${ }^{2}$ With certain modifications and reservations, I hold that these assumptions are sound and legitimate, and that, better than any other hypothesis, they fit in with all the facts at present known to us. It cannot be denied, however, that they are open to attack from various sides. In the first place, there is the preliminary question whether there is an Aryan race-group and consequently an "Aryan epic tradition" at all, If the Aryan speech was imposed by one race upon,other and different races, may not the complex of myths and customs which we are accustomed to and Atyan, be likewise the exclusive property of one race, and have been accepted with the Aryan speech by the inferior races whom the Aryans dominated, and upon. sation be regarded as a special product of the Aryans or as taken regarded as a special product of the Aryans or
civiliser by them from older, presumably Eastern, further to face the hypothesis that the inhabitants of "Cf " "Totemism in Britain," Arch. Rev, June and July 1889, and
"Conditions for the Survival of Archaic Custom," Arch. Rev., January
'1899. 
North-Western Europe, whether Celts or Teutons, had, before this contact with Greco-Roman civilisation, no culture of their own worth speaking of, and that whatever we find of myth, custom, or institution in the early records of both these races is, if not a direct loan from classic culture, at all events profouindly and radically influenced by it. Here the folk-lorist and the student of literature cannot dispense with the aid of the archæologist, using that word in its restricted sense as designating a student of material antiquities. If the folk-lorist, working on the same lines and using the same methods as the palæontologist, reconstructs from existing survivals the picture of a past civilisation, if the student of literature confirms the results thus arrived at, the archæologist has still to have his say. Well-nigh every civilisation has left some material traces of its nature, and if these are found to justify other conclusions from those arrived at by the folk-lorist, the latter must pause and reconsider both his facts and his deductions from those facts. Thus, if early Irish literature, both legendary and legal, gives us an idea of archaic Celtic civilisation altogether different from that derived from the material remains of Celtic antiquity, there will be reason for suspecting the influence of an alien and more highly developed civilisation upon that literature.

These general considerations involve the principle and system of this and succeeding annual reports upon Celtic myth and saga. In setting forth the results arrived at by Celtic scholars, I shall endeavour to bear in view the general trend of anthropological and archæological research. If Celtologists differ in a very marked degree from workers in other fields of study, it will be evident that their methods and results require very careful examination before they can be accepted. ${ }^{1}$ Furthermore, as one of the

I It would by no means follow that such a difference necessarilf implied error upon the part of Celtic scholars It has happened before now that a generalisation, which obtained in many and varying branches of research, has been disproved by the results reached in 
main, if not the main source of the knowledge respecting Celtic antiquity consists of the pre-medixval and mediæval literature of Gael and Brython (i.e., Irish and Welsh) it will be my endeavour to show in what degree the researches of students of literary history affect our estimate of that literature ; in other words, to what extent it may be looked upon as a genuine exponent of Celtic culture. The relations between that early literature and current folk-lore will also demand special attention; and the work of the historian and the archæologist must be examined to see how far it proves, or disproves, the results arrived at by Other methods.

Professor Zimmer's essay upon the Brendan legend is at once the most considerable and the most important contribution of the past year to the history of Irish literature. It is a worthy continuation of the masterly researches which I noticed so fully in my former article. It is difficult to give the pith of studies so complicated and detailed, and jijustice can hardly fail to be done to the master's methods and results in the attempt to summarise them. Briefly peaking, Professor Zimmer may be held to have proved that the mediæval Latin legend of St Brendan is a Christian adaptation of a genre of Irish story-telling, one example of which, dating from a much earlier period and comparatively ittle influenced by Christianity, has come down to us in the "Seafaring of Mael Duin", known to all English-speaking peoples through the Laureate's imitation. Another, and yet earlier fragment of this, one of the favourite categories of Irish story-telling, is probably preserved in the opening to the "Seafaring of the O'Corras", a text only known to us in a much later and, as regards the body of the tale, in a

\footnotetext{
One special branch. So many new facts are coming within the ken of Bevolars, that a-certain amount of over-hasty systematisation is able thes and even those who champion most warmly the fashionthe groories of the day respecting the early history of mankind and ing a very solid human civilisation, can hardly feel that they are build-
} 
compietely Christianised redaction. Professor Zimmer detects in the IIth century Middle Irish texts of these two tales as we now have them, traces of old Irish syntax and vocabulary, and in virtue of this and of numerous considerations drawn from his wide knowledge of Irish history and literary history, he assigns them substantially to the 7 th and 8 th centuries. He argues that the presentment of the terra repromissionis in the Brendan voyage, although modified in a Christian sense, still retains the main outline of Celtic belief concerning the Otherworld, and in section $C$ of his essay he brings together, in support of this contention, a number of instances in which the older Saga literature describes the voyaging of mortal heroes to the Otherworld in a way almost entirely free from all traces of Christianity. It is, to my knowledge, the fullest presentment and discussion of the texts upon which rests our knowledge of early Celtic eschatology.

In the course of his essay, Professor Zimmer gives full summaries of the Latin Navigatio S. Brendani, of the Seafaring of Mael Duin, of the Three O'Corras, and of Snegdus and Mac Riagla, as well as of the Irish Brendan, a composition of the 12th century, in which the Christian eschatological element is even more fully developed than in the Navigatio. In this respect his work can be supplemented by the translations of Snegdus and Mac Riagla, and of Mael Duin, which Mr. Whitley Stokes has published in vols. ix and $\mathrm{x}$ of the Revre Celtique.

1 Whilst Professor Zimmer was investigating the Brendan story, Dr. Schirmer of Leipzig was similarly engaged. He deals with the later medixval history of the legend, which is left unnoticed by the Greifswald professor, as well as with its origin, and the two works should be read together. It is indeed unfortunate for Dr. Schirmer that his sound and conscientious essay should have appeared at the same time as Professor Zimmer's; whatever may be the faults of the latter-and they are not likely to be left unnoticed by his fellow Celtologists-he makes every subject he touches his own by his gigantic industry and his amazing ingenuity. The Brendan literature has been enriched within the last few weeks by Mr. Whitley Stokes' translation 


\section{Celtic Myth and Saga.}

The outcome of this and of the preceding studies of Professor Zimmer is that the Irish Saga literature preserved in the great $\mathrm{IIth}$ century MSS. assumed substantially the form under which it has come down to us in the 7 th and 8th centuries, that this form is practically altogether pagan, and that it gradually become more and more contaminated by Christianity. This, if true, is a result of the highest importance. A pagan 7 th century Irish saga of the variety and complexity of the IIth century texts presupposes a vigorous, complex, and fairly advanced national culture; it is furthermore evident that this must have existed before the introduction of Christianity. The paradoxical opinion has been advanced that Ireland owes its literary and social culture entirely to the Christian missionaries, but surely these had other work on hand than to invent an immense body of literature, pagan both in its general spirit and in its details, for no other purpose, as it would seem, than to afford their successors the opportunity of gradually modifying it in a Christian sense-a task never thoroughly carried out, but which engaged the energies of monkish scribes well on into the 13 th century. Surely, too, however fertilising the effect of the new culture upon the pagan bards and medicine men, it could not have enabled them to create, ex nihilo, such a coherent and complex body of mythic and heroic traditions.

Professor Zimmer thus represents what may be styled the

"Liberal-Conservative" view of Irish antiquity, which, whilst rejecting the "High-Tory" claim to the 3,000 years of authentic history found in the medieval annalists, yet admits the archaic character of the earliest Irish tradi-

of the Irish Brendan Voyage in the Book of Lismore (Lives, pp. 240. 26r), and by the Abbe' Duchesne's critical study on the Lives of St. Malo, in the Jan.-April number of the Rorwe Celligue. As is well rown, an episode in the legend of this saint stands in very close connection with the Brendan voyage. The present writer hopes, before long, to give the pith of all these researches in a general study of the Brendan legend. 
tions. Such criticism as he has received.has been Conservative rather than Radical in its tendency. I ventured in my former article to dispute some of his conclusions respecting the influence of Teutonic upon Celtic tradition, conclusions supported by desperate but unconvincing ingenuity. Professor Kuno Meyer has since shown that many of the philological arguments upon which these conclusions were grounded are open to considerable doubt ${ }^{1}$

To the "Liberal-Conservative" view, again, belongs Mrs. Bryant's bright and ingenious sketch of early Irish history, ethnology, and sociology. She essays to find a meaning in the Irish traditions of successive immigrations from the East and South (traditions which Mons. D'Arbois de Jubainville explained by purely mythological considerations? by interpreting them in the light of current ethnological theories. The Tuatha de Danann are an early immigration, probably Gaelic, from the North-East, and to them the stone circles and circular tombs may be assigned; the Firbolgs, another Gaelic invasion from the South-East through Britain; whilst the Milesian immigration from the South, from Spain, is accepted as fact. The undeniable traces of pre-Celtic population, both in physical characteristics and in social institutions, are accounted for by the pre-Firbolg immigration mentioned in the traditional annals. I cannot but think that the time for any such synthesis is still far off, and the many erroneous, or at least doubtful, statements to be found in the first few pages of Mrs. Bryant's book strengthen my conviction. Is it "certain that at the dawn of Irish tradition all the peoples of Erin spoke one language, and were settling down together side by side

1 Revwe Celtique, rol. $x$. At the same time, Prof. Meyer tells me that his studies upon the text of the Tochmarc Emer have convinced him that this saga exists in two redactions, a pre-Norse and a postNorse invasion one; and he bears witness to the value of the method by which Professor Zimmer has distinguished various strata in the development of the Irish sagas.

- Ls Cercle Mythologique Irlardais, Paris, 1884; and cf. my notices Folk-Lore Jourrat, vol ii. 
under one set of social ideas and institutions" ${ }^{1}$ Nothing less iso, I should say. Again, is it safe to draw any conclusions as to the race-connections of the Firbolgs from the fact that the Firbolg Ferdiad is described as a blonde in the Tain bo Cuailgné? There is the same uncertainty fespecting his personal appearance as there is respecting that of Cuchullain, and until we can satisfactorily explain this uncertainty no conclusion can be drawn, one way or another, respecting the races to which either hero is assigned by tradition. Moreover, what does Mrs. Bryant mean by ithe śtatement on p. 15, that the Irish Gael had no traces fof matriarchalism? If there is a Gaelic kingly hero par excellence, it is Conchobor, and he is always described by his matronymic, Mac Nessa-Nessa's son.

The pinch of salt which the reader should bring with him to the consideration of Mrs. Bryant's first chapter must ever be at hand through the remainder of the book. A fascinating and coherent account of early Irish culture is attained by the simple process of passing over the shadows and the difficulties. But with this caveat the book may be warmly recommended. It groups clearly and suggestively the facts of early Irish society as they may be gathered from texts which are, in part at least, as old as the ninth century. Mrs. Bryant gives, in fact, a modern rendering of the views which the great Irish medizval scholars (down to and including O'Curry) held concerning the social past of the race. Some of these views depart at times widely from actual fact, but their existence constitutes a fact of first-rate importance in the history of Ireland throughout the last 1,000 years, and it is as much the duty of the historian to investigate the rise and development of opinions as to ascertain the nature and sequence of events.

This statement would not commend itself to Archdeacon O'Rorke, a vehement champion of Radical views respecting the early history of Ireland. He quotes in his preface from

Vor. I.

1 Bryant, op. cit, p. 25.

2 Cf, my remarks ante, Arch. Rev, iii, 212. 
Mommsen that it is ridiculous to inquire "into what is neither capable of being known or worth the knowing", for instance, the legendary history of Rome. The straitest historian may well be staggered by such a proposition; the archæologist and folk-lorist will simply pass it by with a smile, knowing full well that it is far more important to understand the genesis and growth of Roman traditional history than to ascertain, could it be ascertained, the year in which some obscure families first settled on the site that was to be Rome, and the names of those families. Be this as it may, the author's quotation indicates his standpoint, that of confirmed scepticism with regard to the pre-Christian history of Ireland, and in especial with regard to the age of the rude stone monuments which are such a characteristic feature of County Sligo. "Ireland in pre-Christian times was utterly unlettered and barbarous ... the outcome of research before long will probably be to bring all or nearly all the existing antiquities of the County within the Christian era." Such are the propositions to which, in the course of a rambling, higgledy-piggledy, but, as regards mediaval and modern Ireland, most instructive and suggestive work, he commits himself with the utmost ingenuity of special pleading. Take, for instance, his treatment of the Carrowmore rude stone monuments. These have hitherto been regarded as pre-historic by sober-minded antiquaries, or, by the older school of Irish historians, have.been brought into connection with various events of the legendary annals, such as the battle of the Southern Moytura. Dr. O'Rorke looks upon the monuments as commemorating the battle of Sligo, fought about 540 A.D., between the invading Ulstermen, comprising both branches of the Northern Hy Neill, and Eoghan Bel, King of Connaught, at the head of all the forces of Connaught. The Connaught men were routed and Eoghan Bel was slain; his head, according to the account preserved in the Anrzals of the Four Masters, here, as usual, favourable to the $\mathrm{Hy}$ Neill, being carried off

1 O'Rorke, op. cit., i, p. xi. 
by the invaders. A Connaught ascount of the battle, contained in the Life of St. Ceallach, preserved to us by the great Sligo antiquary of the 15 th century, Gilla Isa Mor Mac Firbis in his Tribes and Custorns of Hy Fiachrach, states, on the contrary, that the Connaught men buried this monarch, according to his orders, "with his red javelin in his hand ... his face towards the north on the side of the hill by which the Northerners passed when flying before the hosts of Connaught." This was done, and ever after the invading Northerners were routed, panic-stricken, until at last they made a great hosting and raised the body of Eoghan and carried it northwards, and "buried it with the mouth down, so that it might not be the means of causing them to fly before the Connaught men." Dr. O'Rorke finds this monument of Eoghan Bel in a cairn upon the top of Knockarea, a hill overlooking the Carrowmore plain, and looks upon the cromlechs and other monuments of the plain as funereal memorials to the Connaught chiefs. It should be noted that Dr. O'Rorke's identification of the site of this battle differs from that of previous writers, and is chiefly determined by his preconceived notion that the Carrowmore monuments do commemorate' it (though it must be admitted that he has other and ingenious arguments in favour of his theory); that one account of the battle makes the whole hypothesis untenable, and that the other account, whilst speaking of the cairn to the king, says no word about the countless other monuments, described by Petrie, "as the most remarkable collection of the kind in the British islands." By a kind of afterthought Dr. O'Rorke notices the absence of any bronze or iron weapons found in connection with these monuments (" but they may have bcen picked up in the last thirteen centuries"), the presence of firemarks on objects connected with the cromlechs ("but then the Connaught men had their camp-fires for cooking and heating in all directions"), the bones and shells of animals met with in excavations (the "remains of the rabbits and 


\section{Celtic Myth and Saga.}

oysters upon which the Connaught men regaled themselves during their stay on the battle-field"), as possible arguments against the modern date he claims for the monuments. I have bracketed his airy brushings aside of such arguments; they are at least of value.as evidence that humorous ingenuity still remains an Irish characteristic. To fully characterise the scientific method and spirit upon which he plumes himself, it only remains to be added that he does not attempt to cite from the very rich Irish battle literature of the 8th-I Ith centuries a single parallel to what he conceives to have taken place at this 6th century battle. I do not wish to assert that he may not be right in his contention. I only claim that it must be supported by far more serious arguments before it can be accepted.

In the same spirit the so-called Druid's Altar or Giant's Grave at Deerpark is explained as being either the remains of a 6 th century ecclesiastical foundation, or else the grave to which the remains of Eoghan Bel were transferred, as stated in the passage quoted above from the Life of St. Ceallach; or again, "which the writer ventures to think its real destination," it may have been a stone enclosure put up for the purpose of public games, such as we know were held in the district throughout the medixval period, most probably an atena for dog or other animal fights.

Guessing of this kind is as useful or as useless as the imaginings of the older Celtomaniac antiquaries; but when the author applies his system to the elucidation of the mythic stories found in the annals, he runs the risk of gravely misleading. The mythic conflicts between the Tuatha de Danann and the Firbolgs were early localised at Moytura, the localisation probably dating back to the time, 7 th-8th centuries, when the mythology of the race was euhemerised and made to do duty as pre-Christian history. Into the artificial annalistic scheme thus framed various mythic details were gradually adjusted, and in this way the very rich Saga literature belonging to the so-called mythological.cycle took shape. Thus Eochaidh hua 
Flainn, an Irish antiquary of the roth century, has a poem about the battle of Moytura, which gives the framework of the later prose tale; whilst a passage in Cormac's glossary (Cormac was slain in 9r8) shows that a prose tale, substantially the same in character as the existing one, must have been extant at least fifty years before the date of Eochaidh's. poem. In the face of all these facts, Dr. O'Rorke gravely maintains that a battle, fought in 1398 between the O'Connors and the MacDonoughs, "was the source of all the high-sounding traditions connected with the place." Perhaps an even more remarkable instance of his way of treating the most patent facts connected with pre-Christian Ireland may be found in his account of the battle of Cooldruman, the famous fight in which the Ulster clans, at the instigation of their kinsman, St Columba, invaded Connaught and routed the Connaughtmen. The Four Masters have preserved an ancient verse, professedly Columba's invocation before the battle, in which the Saint calls upon Christ, as "his Druid", to side with his kinsmen. The Obvious inference from this passage is that the Druid must have. been a revered personage, and his power recognised as a mighty one, for the greatest of Irish saints to use the word in addressing Christ. To Dr. O'Rorke it only suggests the doubt that Druidism ever existed in Ireland as a specific organised religion."

In one sense, indeed, Dr. Rorke stands on the same level as the older Irish antiquaries; they accepted as literal truth what they found in the early annals, he rejects it as literal truth, but never seems to think that it has a meaning and an importance of its own, and that, if this meaning can be properly ascertained, more light will be thrown upon the Irish race and upon Irish culture than if the date and sequence of all the petty chiefs that ever held sway in that island since man first dwelt in it could be found out.

1 O'Rorke, op. cit., vol. ii, p. 268. 2 Op. cit, vol. ii, p. 8.

${ }^{8}$ Dr. O'Rorke's statements respecting the rude stone monuments of Sligo should be carefully checked by Colonel Wood-Martin's admirable work upon the same subject (Dublin, 1888). 
For those who like to look upon Irish myth, saga, and history as so much raw material for poetic treatment, the new edition of Lady Ferguson's Story of the Irish before the Conquest may be recommended. The bardic tales are' repeated with the unquestioning belief of past ages; but, alas $\mid$ it is largely in the words of modern poets, especially in those of Sir Samuel Ferguson. Thus, whilst delightful reading, the book is deprived of such value as attaches to a simple and faithful retelling of the bardic stories, for instance, to Keating's history. The legends of the Irish race are as valuable to the student of Celtic civilisation as the historic or the monumental record, if not more so, provided always that we have them in their earliest forms and are enabled to trace their growth Lady Ferguson's work unfortunately fulfils neither requirement, and can only contribute to perpetuate false ideas, both about archaic and mediaval Irish culture.

Apart from records of a self-evident mythical or legendary nature, the folk-lorist must keep his eye fixed upon other documents, the interest of which is mainly historical, or theological, as the case may be, but which supply the most valuable hints towards reconstructing the beliefs and practices of our ancestors. Chief amongst these must be reckoned Lives of Saints. Especially is this the case among Celtic peoples. The Celtic "Golden Legend" is perhaps not richer than that of other races in references to pre-Christian myth and cult; its value rather lies in its witness to the infinitesimal difference that separated the pagan "druid"-scothsayer and medicine-man-from the Christian "saint"-medicine-man and soothsayer. Strip the legend of the one of the alien accessories, and it reveals to us a most archaic conception of religion and of social life. Such a story as that of the cleric who "performed fasting against the Lord" 1 because he thought a fellow-cleric had been better treated than he, speaks volumes for the state of the men who told and believed it. Mr.

1 Stokes, Lives, p. xi. 
Whitley Stokes' latest publication will thus be welcomed by all who wish to have a clear idea of the mental and social condition of our forefathers, as well as by all lovers of the mystical, charming Celtic genius. Many of the incidents recorded in these Lives are well-nigh unsurpassed for their mingling of naive humanity and mystical spirituality. Needless to say that the editor has done everything to facilitate the understanding and criticism of his texts. Especially noteworthy from our point of view are pp. xci-cxix of the Introduction, in which the testimony of the Lives to the history and social conditions of Ireland is summarised under commonplaces-pp. cv-cx being given to "Religion and Superstition", pp. cxi-cxii to the "Family", pp. cxiii-cxix to the "State".

Hitherto we have been considering Irish evidence for the existence and nature of early Celtic culture, and chiefly that afforded by literary monuments. It is upon documents, partly literary, partly historical, collated with and controlled by folk-usage, that a suggestive and brilliant attempt to penetrate to the myth and ritual of the Continental Celts is based. I allude to the late M. Cerquand's second series of articles, "Taranous et Thor", in which he supplies and discusses the evidence. for the thesis maintained in the first series. ${ }^{1}$ The value of these articles lies not so much in the conclusion reached-that the Continental Celts possessed a god of thunder, whose role and attributés were much the same as those of the Teutonic Thor-nor in the principle upon which the argument rests, which is, that the pre-Roman and pre-Christian Gaulish culture was not annihilated by the alien and higher elements, but struggled long against them, and was compromised with rather than eliminated-but in the penetrating sugacity with which the most unlikely texts are cross-examined and made to yield witness to this principle. This latter, indeed, was, not so long ago, a quasi-axiomatic assumption with most investigators, but of late it has been

1 Rerue Celtigue, vol. vi, vol. $x$. 
sadly beaten in breach by a school, the tenets of which, if accepted, would reduce our Celtic and Teutonic forefathers to a lower stage of development than that of the contemporary Australian. For I do not know that anyone has essayed to deny the latter's claim to the mythic conceptions which, with his clan and family rules, make up his religion. But as well-nigh every fragment of mythic or heroic fancy found amongst the Teutons (it is against their mythology, as being best known, that the attack has been chiefly directed) has been set down as borrowed from Greco-Roman culture, whether Pagan or Christian, it would indeed seem that our barbaric ancestors must, when they came in contact with ancient civilisation, have occupied as low a place in the culture scale as any we know of ${ }^{1} \mathrm{M}$. Cerquand's articles are a protest, the more valuable because it is implicit, against these doctrines. They demonstrate, upon an important point, that similarity of Celtic and Teutonic myth which we should naturally expect, and they demonstrate it by the analysis of documents-sermons of Christian apologists, decisions of synods, official citations of or references to local usage-which are above all suspicion, and against which none of the arguments urged against purely mythological texts are valid.

The transition from the Continental to the Brythonic branch of the insular Celts is easy. Professor Rhys has again affirmed the view held by the majority of scholars, that the Gaulish tribes (at least those ruling classes among them which came in contact with Rome) and the Brythons belong to a secondary wave of Celtic settlement througbout the west of Eprope, and he has connected this wave with the Dorian settlement in Greece, and with the entry of the Oscan tribes into Italy.? His arguments are

1 I do not of course attribute this extreme view to any one member of the "borrowing school". But each one signalises himself by picking out some special feature as a proof of the general thesis, and the effect of accepting all their contentions would be as I have stated.

" "Early Brit. Ethnology," Scott. Rev., April. 
mainly philological; I greatly doubt whether they could be supported from the myth and custom-store of these races. As far as such portions of Brythonic (Welsh) literature are concerned, which are in any measure entitled to be called mythic, I should not be at all surprised if future research connected them directly with Gaelic (Irish) myth. ${ }^{1}$ The problems involved are of the utmost complexity. The literary documents on the Brythonic side fall, broadly speaking, into two classes, the one consisting of poems and tales, found only in W.elsh, to which all manner of dates from the 6 th to the I2th centuries have been assigned; the other, the Arthurian romance, comprising Welsh, Latin, and French tales and poems, the subject-matter of which is British. It is still disputed whether the heroic and mythic traditions of the first class belong to the North or the South of our island. The former theory, worked out independently by Mr: Skene and Mr. Stuart Glennie, is generally accepted. It assumes that the traditions preserved by the poems associated with the names of Aneurin, Merlin, and Taliessin originated in Southern Scotland and North-Western England, and were transplanted to Wales in the fifth and following centuries; in which case they would seem to be more worthy of attention from the investigator of Celtic origines than if they belonged to the South of England, which was longer subjected to Roman and Christian influence. How fundamentally this affects our usage of the early Welsh documents is evident. No recent contribution has been made towards the settlement of this question. It is to be hoped that Professor Rhys in his forthcoming work on Arthur will discuss the Welsh sources, the genuine pre-Christian character of which was assumed by him in the Hibbert Lectures.

The second class of documents, the Arthurian romance,

It is significant in this connection to note that Professor Thurmeysen finds Irish characteristics in the Juvencus glosses, hitherto regarded as one of the oldest specimens of Welsh (Rev. Cell.. Jan.April, 9l). 
gives rise to further complication. The majority of the texts are in French, the oldest, paleographically speaking, are in Latin. That the whole superstructure is Celtic no one would affirm, but even the fact that it rests in any large measure upon a Celtic basis is denied by a school at the head of which stands Professor W. Förster of Bonn, and which counts among its ranks, inter alios, the most distinguished German disciple of Professor Bugge, Dr. Wolfgang Golther of Munich. The latter's article, cited at the head of this report, sums up tersely and ably the views of this school. Moderate opposition thereto is made by the greatest living authority in this field of scholarship, Mons. Gaston Paris, and his group of pupils, chief among them Mons. E. Muret. The French school by no means advocates the Celtic nature of the Arthurian romance in such a thorough-going way as, say, Professor Rhys, Ferhaps because it has paid less attention to the Irish sources, the examination of which reveals with such startling clearness the fact that well-nigh all the leading scenes and situations of the Arthur myth have their parallels in the Irish saga of the $I I$ th and preceding centuries, and may therefore be considered Pan-Celtic.

The most important work that has recently appeared in this field of research is undoubtedly Mons. Gaston Paris' survey of the Arthurian metrical romance (Hist. Lit., vol. $\mathbf{x x x}$ ). Nor is its interest exclusively or even mainly con'fined to the Celtic student; every "storyologist" should have it at hand. I may be permitted to trench for a moment on Mr. Hartland's province, and to point out that a theory deriving the current European folk-tales from mediaval. romance has far more to say for itself than the Indian importation hypothesis championed by Benfey and Mons. Cosquin and Mr. Clouston. Needless, then, to insist upon the value to the student of a work which affords a bird's-eye view, admirable in its clearness and precision, over the most important and most intricate section of mediæval romance. One instance must suffice to illustrate how 
investigations, which at first blush seem to belong wholly to literary history, may involve the wider problems of comparative mythology and folk-lore. A fragmentary German Arthurian poem of the 12th century, "Manuel et Amande," the translation of a now lost French work, tells of Arthur's death, caused, it would seem, by a cat. Now Arthur's combat with a great cat is an episode often alluded to in the later romance, and is fully described in the Vulgate Merlin.1 The cat was fished up on the shores of the Lake of Geneva, nourished by its captor, whom in return it strangled, together with the rest of the family, and became thereafter the terror of the country side. Only after a desperate conflict was Arthur successful. This is onc version. But André de Coutances, an Anglo-Norman poet of the early I $3^{\text {th }}$ century, is at some pains to refute the idle tales current in his days how Arthur was overcome and slain by Capalu. This name turns up in other poems of the same date, e.g., in the Bataille Loquifer, the title of which reveals its Celtic provenance (Loquifer $=$ Lok Ifern and Ifern=Hell). Now the oldest series of Welsh triads, which can be carried back, paleographically, to. the first quarter of the I $3^{\text {th }}$ century, tells anent the Cath Palug a story almost precisely similar to that of the Vulgate Merlin,? and we can hark back still further on Welsh ground. The Black Book of Caermarthen is a Welsh MS. of the last quarter of the 12th century; a poem therein, unfortunately incomplete, describes how Cai warred against the Cath Paligg, "nine score before | dawn would fall for its food | nine score chieftains."3 In this instance, at least, the priority of the Welsh version of the episode cannot be seriously questioned. The Black Book poem belongs to the very oldest stage of the Arthur-saga, that wherein Arthur himself is the chief protagonist, and $\mathrm{Kai}$ and Bedwer his chief and constant companions; a stage, be it

${ }^{1} \mathrm{Ch}$. lexiii of the E.E.T.S. edition.

2 $Y$ Cymsurodor, vii, 131-132.

1 Skene, Four Ancient Books, i, 264. 
noted, almost unrepresented by the French romances, which for the most part picture Arthur as a roi faindant, and profoundly degrade the characteristic figure of Kai. Here, too, philology lends us her aid: Cath Palug (Old Welsh Paluc) would readily become Capalu or Chapaluthe reverse process is impossible. Is then the combat of the race hero and the monstrous cat a genuine fragment of Brythonic saga? Another possibility must be faced before this is granted. The already cited Bataille Loquifer describes the monster as having "tête d'un chat, pieds d'un dragon, corps d'un cheval, queue d'un lion." If this description goes back to a Welsh original, it would seem that the Cath Palug was a sort of Chimara. Are we then to look upon this episode as a Brythonic variant of a Pan-Aryan myth descriptive of a strife between the hero and a tempest-demon, or. only as the creation of some classically read Welshman?

These considerations have carried us away somewhat from Mons. Gaston Paris' work, some obiter dicta in which I would specially notice. $A$ propos of the Vengeance de Raguidel, he says: "D'ailleurs cette exaltation conventionelle de la femme est inconnue d la plus ancienne poésie Celtique à laquelle appartient cette malicieuse histoire, comme aussi celle de la Corne enchantée ou du Court Manteau." But do these chastity-test stories belong to "la plus ancienne poésie Celtique", and was it not Celtic poetry, on the contrary, that largely inspired the conventional exaltation of woman in medieval romance? Again, the dragon-fight in Tristan induces the remark, "l'épopée Celtique contient comme toutes les épopés des éléments adventices ¿ "côté de données nationales." Granted, but how are these to be distinguished? Is every element to be set down as adventitious that

3 But for the lucky preservation of this Black Book fragment our German friends would, doubtless, have stood out for the priority of the Merlin version over that of the Triads.
I G. Paris, op. cit., 220.
Op. Oil., 64 .
' Op. cit., I19. 
can be widely paralleled from other cycles? If so, the "données nationales" may safely be set down as the least portion, not only of the Celtic but of every other epic cycle.

The determination of earlier Celtic elements in the Arthurian romances has unfortunately been complicated by questions respecting the relations between some of the Mabinogion and the poems of Crestien de Troies. As is - well known, the Welsh tales (found complete in the Red Book of Hergest and fragmentarily in much older MSS.) to which the title Mabinogion is commonly though incorrectly applied, fall into four classes. One, comprising the Lady of the Fountain, Peredur, and Geraint, is obviously connected with the Chevalier au Lion, the Conte du Graal, and the Erec of the French poet. ${ }^{1}$ The connection is manifestly closest in the case of Geraint. Herr $\mathrm{K}$. Othmer's exhaustive, elaborate, and careful demonstration that the Welsh tale is directly taken from the French poem, of which indeed it is in many parts a simple translation, has thus somewhat the nature of a breaking in of open doors. But Herr Othmer, a pupil of Professor Förster's, draws far wider conclusions from the fact he has proved than he is at all entitled to. Because the $13^{\text {th }}$ century Welshman adapted Crestien's poem, it by no means follow's that the latter may not be based upon earlier Celtic lays. The merit of the 12th century French poets lay largely in the unity they gave to independent and often discordant episodic ballads or tales, and it is easily conceivable that the superior literary qualities of their works should win acceptance for them even in the original home of the Arthur cycle. Moreover, on Herr Othmer's own showing, the Wellsh tale has retained traits of early Celtic

\footnotetext{
${ }^{1}$ The other three classes are (I) what may be called the non-French

(2) Turian Mabinogion, Kilhwch, and the Dream of Rhonabwy;

(3) The Mabinogion proper, Pwyll, Branwen, Manawyddan, Math'; of Welsen Wledig and Lludd, which apparently represent the stratum of Welsh legend which Geoffrey worked up in the Hist. Brit.
} 


\section{4}

\section{Celtic Myth and Saga.}

manners which are missing in the French poem. When Geraint is contending against the. Knight of the Sparrow Hawk, the latter is incited to do valiantly.by the exhortations of his dwarf, and Geraint is in like manner spurred on by the reproaches of the dispossessed earl. Hers Othmer remarks that this episode, wanting in Crestien, is contrary to the usages of French chivalry. Be this as it may, the combatants in the Welsh tale bear themselves do rival warriors in the oldest Irish sagas. "If it be I that shall begin to yield this day, thou art to excite, reproach, and speak evil to me, so that the ire of my rage and angcr may grow more upon me," says Cuchullain to his charioteer, Laeg, in the Tain bo Cuailgne. And the Highland peasant of to-day, when he tells of the marvellous feats of Conall Gulban, places Duanach at his side to spur and egg him on.1 Is it not more likely that the Welsh story-teller was following an early lay, describing a combat of Geraint's? than that he introduced this Celtic trait into his translation from the French?

This is not the only instance in which ignorance of Celtic history and literature has led Herr Othmer astray In proof that Geraint is derived from Crestien's poem, he justly cites the fact that the Welshman took his heroine's name, Enid, from the French poet ; but when he explains this on the ground that "older Celtic tradition had no heroines", he is wholly in the wrong. On the contrary; nowhere is the influence of the "heroine" more prepon derating than in the Irish heroic sagas, nor do the epic traditions of any race offer heroines of more individual energy and character than Medhbh, and Deirdre, and Blathnaid, to cite the first names that come to hand.

1 Campbell, No. lavi.

- Indeed "Das Ewig-weibliche" in the early sagas moves Professor Zimmer, writing from the chaste shores of the Baltic, to a four-pages long lamentation over "den ausgeprägten sinnlichen $\mathrm{Zng}$ in Irish" literature ( $0 p$. cit., $28 \mathrm{I}$ et seq.). Lest any should feel tempted to learm; old Irish in consequence, I hasten to add that they would find the Irish sagas, pace Professor Zimmer, of by no means such an excitinf. character as, let us say, Lemprière. 


\section{Celtic Myth and Saga.}

Again to explain the method of abridging Crestien, found in the Welsh tale, on the ground that "der Kelte liebt nicht ausfuihrliche Darstellungen", is to go dead against the facts. If there is one thing the "Kelte" does like it is "ausfïhrliche Darstellungen"; indeed, no better instance of the detailed and vividly picturesque descriptive passages which characterise Celtic traditional literature in all its stages could be found than in one of the Mabinogion, the Dream of Rhonabwy.

My strictures upon Herr Othmer's essay must not be misinterpreted; I most cordially recognise the value of the patient and laborious researches by which he and so many other German scholars are determining the correct nature of medixval texts. But to decide problems in which the most intricate ethnological and sociological factors are concerned something more is needed than the method of acute and patient comparison by which a magazine writer justifies a charge of plagiarism against a popular novelist.'

1 I may cite here the titles of a few pamphlets and articles relating to the Tristan story, which has been one of the best studied sections of the Arthur-cycle during the past few years:-T. Muret, Eilhart d'Oberg'et sa source franfaise (Romania, xvi, 288-363); W. Golther, Die Sage von Tristan und Isolds (Munich, 1887); F. Novati, Un twovo ed un vecchio frammento del Tristran di Tommaso (Studi di Flogia rom, vi, 369-515); H. Warnecke, Mfetrische und sprachliche Abhandlung veber das dem Berol sugeschriebene Tristran fragment (Erlangen, 1881); E. Löseth, Tristran romanemsgammelfransks prasahandskrifter in Pariser Nationalbibliotheket (Christiania, 1888). These various treatises are briefly reviewed by Prof. M. Wilmotte (Moyer-Age, Jan. 1890), who leans unduly, in my opinion, to the side of Dr. Golther, but whose article enables a clear and succinct view of the very perplexing questions connected with the earliest French versions. To conclude the enumeration of "Arthurian" monographs, Imast note Geheimrath Alb. Schulz' (San-Marte) Ueber den Bildungsgang der Gral und Parrival Dichtung in Frankreich und Deutsckland (Zeits. für deutsche Philologie, roii, 3,4 ). Written in the veteran's eighty-eighth year, this essay testifies to the undying love of its author for the studies of which be was the pioneer sixty years ago. It is 
Turning aside from mediæval Celtic documents, let us see what has been done towards the collection and the elucidation of living folk-lore. Lady Wilde, in her new book, at once adds to the debt which all who cherish Irish tradition owe to her, and places her reviewer in a somewhat embarrassing position. Much of the matter is excellent, but the arrangement is even faultier, and the lack of all those indications which the student desiderates even more complete than is usual with her. Her work can hardly be recommended save to the scholar, capable himself of the critical task which the author should have performed for him, or to the general reader, to whom any book stands on the same level as a page of Tit-bits; the one will be thankful for the materials, the other for charm and entertainment. I must confess, however, my doubts as to how far Lady Wilde faithfully reproduces the facts of living Irish tradition, and whether she does not unconsciously lend them the tone and colouring of her own imaginative and poetic temperament.

Mr. Curtin's MIyths and Folk-lore is a most welcome addition to the small stock of folk-tales collected in Ireland. Although no information is given about the narrators, the tales are obviously genuine, and as obviously translated with spirit and verve. It is interesting to compare them with the West Highland tales collected by Mr. MacInnes and annotated by myself (cited below as Tales), concerning which I think it unnecessary to say anything, as the volume is in the hands of most readers of Folk-Lore.

Mr. Curtin's tales are twenty in number. No. I. The Son of the King of Erin and the Giant of Loch Lein is a variant of Tales, No. I. No. II. The Three Daughters of King O'Hara : a Beauty and Beast tale. No. III. The Weaver's Son and the Giant of White Hill : a task story, in which a brother has to seek his three sisters, carried off before his birth. No. IV. Fair, Brown, and Trembling,

to be regretted that the purely critical portion of the essay should be based upon Birch-Hirschfeld's erroneous exposition of the relations betwee $\mathrm{n}$ the works which make up the Grail-cycle. 
is a Cinderella tale. No. V. The King of Erin and the Queen of Lonesome Island: mysterious love-child who accomplishes the task which the legitimate son fails in. No. VI. The Shee an Gannon and the Gruagach Gaire: a variant of Tales viI, with intercalation of the King of Erin's tale in Tales III. No. VII. The Three.Daughters of the King of the East and the Son of a King in Erin : envious stepmother and swanmaid guest. No. vIII. The Fisherman's Son and the Gruagach of the Tricks: Master Thief story, winding up with transformation combat. No. IX The Thirteenth Son of the King of Erin : eldest best; another variant of Tales vill. No. $\mathbf{X}$ Kil Arthur. The best example in the book of the class of tales so common in the West Highlands, of which Conall Gulban and Manus are such good examples, orally preserved fragments of a Gaelic Heldensagc, which assumed quasi-literary shape in the 12th and following centuries. It contains (pp. 178 et seq.) a variant of the Visit to the Fairy Brother-in-law (here, father-in-law), which I had noted (Tales, p. 47I) as unknown to me. No. XI. Shaking Head: grateful dead tale. No. XII. Birth of Fin Maccumhail. Valuable Ossianic tale with details I have not met elsewhere. Fin gets through his trials and combats, thanks to Bran's advice. The tale of how Fin guarded Tara against fairy foes, found in the 15 th century Agallamk na Senorach, is here mixed up with the fight against the Carlin and her three sons. No. XIII. Fin Maccumbail and the Fenians in the Castle of Fear Dubh. Variant of the Fenian tale best known as the Fairy Palace of the Quicken Trees. The revivifying Carlin also appears in this tale, with attributes that strikingly recall the Morrigan, the battle goddess of the pagan Irish. No. XIV. Fin Maccumbail and the Knight of the full Axe. Conall Gulban like adventures of Finn aided by a fairy dwarf. No. XV. Gilla na Grakin and Fin Maccumhail. Fine tale, embodying, inter alia, a variant of first part of Tales II, and the King of Erin's tale (Tales III). The black sail incident to announce hero's death is likewise here. No. XVI. Fin Maccumbail, the Seven Brothers, and the King of France: variant of second part of Tales II. No. XVII. Black, Brown, and Gray: confused and fragmentary Fenian tale. No. XVIII. Fin Maccumbail and the Son of the King of Alba. A strong servant tale, with variant of the Fairy Palace of the Quicken Trees. No. XIX. Cuculin. Cumulative unspelling quest tale, with the unknown son episode introducéd at end. No. XX. Oisin in Tir na n-og.

\footnotetext{
The community of incident and of subject-matter between the Scotch and Irish Gaelic tales which I have insisted upon so strongly in my notes to Mr. MacInnes's Tales comes VOL. 
out in Mr. Curtin's volume afresh, but certain differences make themselves felt. It might seem as if the unrivalled picturesqueness and body of the Scotch Gaelic tales were due to a mingling of Celtic and Teutonic tradition. Or it may be that the closer communion of the Western Highlanders with a wilder and more varied nature than that of Ireland has fostered and preserved in them a keener sense of kinship with the tone and temper of the traditional heroic age.

In this field of research the publication of documents has only gone far enough to enable three or four solutions of the complicated problem before us to be distinguished. We are not as yet in a position to decide in favour of this or that solution. The chief desideratum is the publication of the rich stores of Irish MS. tales belonging to the last two centuries. We shall then be able to judge whether the current folk-tale is, as some hold, a mere derivate of the mediaval or pre-mediaval sagas. through the medium of these MS. versions, or whether it does not rather represent the basis of the sagas. I incline at present to this latter view, in favour of which I have adduced some evidence in my notes to Mr. McInnes's tales. The Folk-Lore Society has drawn the attention of the Royal Irish Academy to the necessity and importance of this work. What is wanted is a revival, with wider scope and more scholarly aim, of the old Ossianic Society, to comprise among its ranks Gaels of Ireland and of Scotland as well as all who have at heart the preservation and the study of Celtic thought and Celtic fancy.

The new material offered to the student of Celtic folklore, valuable though it be, presents no great novelty, and favours no revolutionary theorising. Now, apart from the discussion of the traditional literature with which I have already dealt, the only serious contribution that has been made recently to the interpretation of the popular lore of both Scotland and Ireland may well be styled revolutionary, though it is not entirely novel. I allude to Mr. MacRitchie's 
articles in the fourth volume of the Archeoological Review. His thesis, briefly put, is that the fairy belief has its basis solely in the traditions connected with a short, dark, very strong race, who dwelt in earth-houses, and were subdued by the invading Celts, but retained separate, often independent existence, well on into historical times. Ethnologically, he conceives this race to have had Finnish affinities; historically, to have been known as the Picts. Unfortunately for himself, Mr. MacRitchie attempts to prove far too much; moreover, he indulges in etymological guesswork, such as that the Feinne (the warrior companions of Finn mac Cumhail) were of Finnis/h race, and that the Gaelic word for fairy, Sidhe (pronounced "Shee"), has some possible connection with the 7'shuds, a race of Northern Europe and Asia, ethnologically akin to the Lapps. I have attempted to show (Tales, pp. 418-20) that his arguments respecting the Feinne are based upon a false appreciation of the Fenian documents; indeed, his whole treatment of sources seems to me as unscientific as his etymological theorising. Nevertheless, I must frankly say that he has collected and marshalled an array of facts deserving the most serious consideration; and I think he may be allowed to have made out his case to this extent, that the historical elements in the fairy belief are more numerous and potent than is held by the great majority of students.

Whilst it cannot be said that the past eighteen months have very greatly forwarded our study, yet steady progress has been made. Our knowledge has been enlarged, our criticism is sounder, because better informed. But in no one branch of Celtic antiquities has sufficient material been collected, or has the existing material been sifted with sufficient care to justify dogmatism. At the outset of this article $I$ indicated as approximately true, the hypothesis that the Celtic inhabitants of these islands possessed a considerable archaic culture, many elements of which are preserved to this day in the living folk-lore of these islands. This is substantially the opinion expressed by Mr. York Powell in 
his article on "Recent Research on Teutonic Mythology" (ante, p. 126): "It is not true that Teutonic heathendom is permeated by Latino-Greek or Judæo-Christian thought ... the good old mythology and ritual went on as old wives' fables and charms many a century after, and survive in the fairy tales and superstitious observances of to-day." I believe the position to be as true in the Celtic as in the Teutonic field, and that it can only be strengthened by further research.

ALFred NutT. 